\title{
LAND DEGRADATION ISSUES IN NEPAL AND ITS MANAGEMENT THROUGH AGROFORESTRY
}

\author{
Anil Kumar Acharya (BSc) ${ }^{1}$ and Narayan Kafle (BSc) ${ }^{2}$
}

\begin{abstract}
Land degradation is major challenge of Nepal. The paper focuses mainly on causes and consequences of land degradation and their management approaches. Land degradation may occur through different physical, chemical and biological processes induced directly or indirectly by human activities like deforestation, shifting cultivation, overgrazing, steep slope farming, over use of chemical fertilizers and forest resources. These create many social problems like poverty, poor health and nutrition and demographic dynamics by lowering agricultural productivity. Agroforestry approaches like use of Multi Purpose Tree Species (MPTs), relay-cropping, terracing and contour cultivation, strip and alley cropping are appropriate to fulfill the needs of low resource farmers by restoring and increasing land productivity. The potentiality of the approach can be made more effective through holistic efforts, based on needs with active participation of farmers in planning and implementation stage.
\end{abstract}

Key Words: Biodiversity, deforestation, ecosystem, natural resource, productivity, erosion

\section{INTRODUCTION}

Land is one of the major natural resource of a developing country like Nepal. More than $90 \%$ of the population is dependent upon the land for their fulfillment of basic needs (food, fodder, fuel, fiber and timber) (LRMP, 1986). Land degradation is decline in land quality or reduction in its potential productivity of land. Land degradation may occur through different physical, chemical and biological processes which are directly or indirectly induced by human activities. These include soil erosion, compaction, acidification, leaching, salinization, decrease in cation retention capacity, depletion of nutrient, reduction in total biomass carbon and decline in biodiversity. Soil structure is major factor for all forms of degradative processes. It also affects the provision of ecosystem services. Human activities are responsible not only for the degradation of land but also important for improvement of land through prevention, rehabilitation and reclamation (MoEST, 2008).

Nepal has extreme climate ranges from subtropical to arctic (High Mountain) and vegetation ranges from sub tropical forests to arctic like Tundra. Nepal has been divided into mainly 3 physiographic regions Terai, Hills and Mountains of which the mountains and hills make up about 83 percent of the area, and the 17 percent Terai. It shows that about $1 / 4^{\text {th }}$ and $1 / 3^{\text {rd }}$ of the area is suitable for agriculture and forest covers respectively. Much of the hill and mountain areas are very fragile and vulnerable to landslides. Terai lands are regularly threatened by flooding and sedimentation (Karkee, 2004).

More than 9 million hectares of forest are being converted into non forestland, and at least double that amount of forest ecosystem is being fragmented and degraded each year over the world. Converted land is generally agriculturally unproductive, biologically impoverished, and more flammable than the forests (Uhl and Buschbacher, 1985; Uhl, 1987). Rural livelihoods in

1 MSc student and Horticulture Development Officer, anil-acharya@hotmail.com

2 MSc student: narankaphle@gmail.com 
the hills of Nepal are directly linked with forest ecosystems for human needs, animal rearing, crop production, and providing environmental and spiritual needs. As a result, there is greater human pressure on the hill forest ecosystems due to which about 200 hectares per day of forest conversion in non-forest land, or degradation and fragmentation into shrub/bush lands. These cause loss of plant species and high levels of erosion resulting in further loss of soil nutrients. Lowering agricultural productivity from loss of soil nutrients has lowered rural communities' income and livelihood support. This has adversely affected poverty levels, resulting in $45 \%$ of hill population having to survive below the poverty line in Nepal (Gautam, 2000).

\section{OBJECTIVE}

The objective of the paper is to present causes and consequences of land degradation and their management approaches through agroforestry. The paper also aims to way out restoring land ecosystem and improving rural livelihoods through agroforestry.

\section{DISCUSSION}

\section{LAND DEGRADATION: STATUS, CAUSES AND CONSEQUENCES}

Land degradation is one of the greatest challenges faced by Nepal. Both the natural conditions and human activities have contributed to the degradation of land in Nepal. Some of the major causes of land degradation are fragile geological structure, forest fire, avalanches and dry landslides in which increasing population, fragile economy and sometimes farm policies add fuel to it in its natural condition. Natural calamities like landslides in the hills, drought in the most of the areas of the country and flooding in the foothills and the Terai have frequently occurred. Most of all, flooding is a major cause of land degradation leading to the poor socio-economic conditions and the deterioration of the natural ecosystems. Anthropogenic causes such as deforestation, excessive use of chemical fertilizers, overgrazing, construction works, and unscientific farming in the hills (steep slope) have resulted in the loss of flora and fauna, erosion of top soil, occurrence of land slides in the hills and flooding in the plain areas. This has led to severe environmental degradation leading to poor socio-economic condition and disruption of natural ecosystems in Nepal (Karkee, 2004).

The repeated pressure of grazing on grasslands beyond its carrying capacity, shifting cultivation in the mountains and overgrazing in the open public lands lead to land degradation and damage the ground vegetation and grassland ecosystems. The heavy grazing pressure in the mountain areas has speeded up the soil erosion, which lead to increase run-off and compaction of soil. Cultivation on steep slope without taking considerations of improved farming such as terracing, use of organic manures has contributed to increase in soil erosion resulting in high water turbidity which leads to harmful effects to the aquatic flora and fauna including fish species. Development activities such as construction of roads, buildings, dams have added effect to it (Neupane and Thapa, 2001). In Nepal, land and forest resources have been intensively used to meet the basic requirements of food, fuel-wood, fodder, and small timber (Karkee, 2004). 
Rivers in Nepal have damaged more than 400,000 hectares of productive agricultural lands (LRMP, 1986). The Shiwalik hills and middle mountainous regions are highly vulnerable to soil erosion. The extent and severity of damages have increased continuously due to frequent changing nature of mountain-rivers. Farmlands near river banks are washed away by flooding, crops are ruined and widths of rivers widen every year during monsoon. Nepal's rivers carry around 336 millions tons of soil per year to the main river systems entering to India (Brown, 1981). The bed level of Terai's rivers has been rising by $35-45 \mathrm{~cm}$ annually (Dent, 1984). The productivity of riverside lands has been seriously affected by silting, flooding and deposition of pebbles. Furthermore, the river-damaged areas of middle mountains of Nepal suffer from excessive grazing pressures of domestic animals. Pioneer plants which are indicator species for degraded lands like Imperata cylinderica, Saccharum munja, and Cassia occidentalis have colonized in such areas (Kafle, 1995). Nearly $45.5 \%$ area of the country is seriously affected by water erosion. Similarly, $4 \%$ area mostly in higher altitude and trans-Himalayan region is affected by wind erosion. Land degradation due to chemical and physical processes is less than $2 \%$ of the total area of the country (Gautam et al., 2003). The land area under degradation is presented in table 1.

Table 1. Land area under degradation

\begin{tabular}{|c|c|c|c|c|}
\hline S.N. & Land use category & $\begin{array}{l}\text { Degraded area } \\
\text { (million ha) }\end{array}$ & $\begin{array}{l}\text { Total land area } \\
\text { (million ha) }\end{array}$ & $\begin{array}{l}\% \text { of degradec } \\
\text { land }\end{array}$ \\
\hline 1 & Forest (poorly managed) & 2.100 & 5.828 & 36.02 \\
\hline 2 & $\begin{array}{l}\text { Agriculture (poorly managed } \\
\text { slopping terraces }\end{array}$ & 0.290 & 2.969 & 10.00 \\
\hline 3 & $\begin{array}{l}\text { Pasture/rangeland } \\
\text { (degraded) }\end{array}$ & 0.647 & 1.75 & 37.00 \\
\hline 4 & $\begin{array}{l}\text { Areas damaged by floods and } \\
\text { landslides (1984-2003) }\end{array}$ & 0.106 & 11.551 & 0.92 \\
\hline \multirow[t]{2}{*}{5} & Forest encroachment & 0.119 & 5.828 & 2.04 \\
\hline & Nepal & 3.262 & 11.551 & 28.24 \\
\hline
\end{tabular}

Source: MoEST, 2006.

The land degradation is associated with soil erosion on the hill slopes, sedimentation/siltation in river valleys and the Terai which reduce crop yields due to decline in soil nutrients, acidification, and pollution. The estimated annual soil erosion is given in table 2 .

\section{AGROFORESTRY SYSTEM FOR LAND DEGRADATION MANAGEMENT}

Farmers have cultivated trees on farm from time immemorial. Agroforestry system in Nepal is diversified and integrated with livestock, trees and crops. Any change in any component of the whole system will have effects on the other components. Households keep different types of animals for meeting their livelihood. Households plant fodder trees on under utilized lands. The average fresh fodder requirement for each household is $73.68 \mathrm{~kg} / \mathrm{day}$. The increased number of fodder trees on farm enables one third of the households to practice stall-feeding. 
However, the rest of the households still practice both stall feeding and grazing due to lack of land to produce sufficient fodder to maintain sound health of animals (Regmi, 1998).

Table 2. Estimated annual soil erosion

\begin{tabular}{l|l|l|l|l}
\hline S.N. & Land use category & $\begin{array}{l}\text { Erosion rate } \\
\text { (ton/ha/yr) }(1)\end{array}$ & $\begin{array}{l}\text { Area } \\
\text { (million } \\
\text { ha)(2) }\end{array}$ & $\begin{array}{l}\text { Approximate soil } \\
\text { loss } \\
\text { (ton/yr)(1x2) }\end{array}$ \\
\hline 1 & Well managed forest & $5-10$ & 2.71 & $13.55-27.1$ \\
2 & Poorly managed forest & $25-40$ & 1.559 & $38.98-62.36$ \\
3 & Well managed paddy terrace & $5-10$ & 1.50 & $7.5-15.00$ \\
4 & Well managed bari (dry terrace) & $5-15$ & 0.83 & $4.15-12.45$ \\
5 & Poorly managed sloppy terraces & $20-100$ & 0.29 & $5.80-29.00$ \\
6 & Degraded rangeland/open land & $40-200$ & 1.75 & $112.4-562.00$ \\
\hline & Total & & 9.699 & $182.38-707.91$ \\
\hline
\end{tabular}

Source: MoEST, 2006.

The components of agroforestry exploit different vertical layers both above and below ground which signifies greater resource utilization efficiency for optimizing resource use. Farmers can play leading role in development and testing of MPT technology, assessing on-station trials, conducting researcher-designed and farmer-designed trials, and providing feedback to the researchers. Hence, efforts are needed to model and assess the long-term impacts of the multipurpose trees on productivity (Karkee, 2004).

It has been reported that financial returns generated from agroforestry system are generally much higher than return from continuous unfertilized food crops around the developing world. The higher return associated with agroforestry can translate into improved household nutrition and health, particularly when the income is controlled by women. Monitoring and impact assessment studies need to give more attention to how agroforestry affects household resource allocation and consumption (Fleming, 1983).

Agroforestry can contribute to human nutrition through increased production and availability of particularly nutritious fruits and leaves Improving livelihood support in lessening rural poverty along with degraded hill environmental restoration on highly populated lower and mid hills are prioritized in the plan of Nepal. The government of Nepal has launched its Hills Leasehold Forestry and Fodder Development Project with assistance from FAO and IFAD to achieve the national goal. The government has leased degraded forestlands and granted the leasehold land tax-free to eligible families who are below the poverty line, and has provided training and minimum inputs. This has resulted in an increase in forest coverage of up to $70 \%$, and an increase in the income levels of leasehold families during the last seven years. This increase in families' income helps to support children's schooling, health and daily family expenses (Gautam et al., 2003). 
Integration of trees in the production system

Different agroforestry species used for the management of land degradation are given in table 3 (Kerkhoff, 2003).

Table 3. Agroforestry species used for land degradation management

\begin{tabular}{|c|c|c|}
\hline Local name & Scientific Name & Uses \\
\hline \multicolumn{3}{|l|}{ Fodder } \\
\hline Badahar & Artocarpus lakoocha & Fodder, fuel, fruit \\
\hline Bhatmase & Flemingia congesta & Fodder, fuel, soil conservation \\
\hline Dabdabe & Garuga Pinnata & Fodder, fuel \\
\hline Ipil Ipil & Leucaena spp. & Fodder, fuel, soil conservation \\
\hline Kabro & Ficus lacor & Fodder, fuel, soil conservation, pickle \\
\hline Khanyu & Ficus semicordata & Fodder, fuel, fruit \\
\hline Khasreto & Ficus hispida & Fodder, fuel \\
\hline Kimbu & Morus alba & Fodder, fuel, sericulture \\
\hline Koiralo & Bauhinia variegata & Fodder, fuel, pickle \\
\hline Rahar & Cajanus cajan & Fodder, fuel, food \\
\hline Kutmero & Litsea monopetala & Fodder, fuel \\
\hline Tanki & Bauhinia purpurea & Fodder, fuel \\
\hline \multicolumn{3}{|l|}{ Fuelwood/Timber trees } \\
\hline Bakaino & Melia azedarach & Timber, fuel, fodder, medicinal \\
\hline Sal & Shorea robusta & Timber, fuel, fodder \\
\hline Sissoo & Dalbergia sissoo & Timber, fuel \\
\hline \multicolumn{3}{|l|}{ Fruit trees } \\
\hline Amba & Psidium guajava & Fruit, fuel \\
\hline Amp & Mangifera indica & Fruit, fuel \\
\hline Anar & Punica granatum & Fruit, fuel \\
\hline Aru & Prunus persica & Fruit, fuel \\
\hline Bhui-katahar & Ananus sativus & Fruit, soil conservation \\
\hline Kagati & Citrus aurantifolia & Fruit, fuel \\
\hline Kera & Musa sapientum & Fruit \\
\hline Lichi & Litchi chinensis & Fruit, fuel \\
\hline Mewa & Carica papaya & Fruit \\
\hline Naspati & Prunus communis & Fruit, fuel \\
\hline Nibuwa & Citrus lemon & Fruit, fuel \\
\hline Rukh-katahar & Artocarpus integrifolia & Fruit, fuel, fodder \\
\hline
\end{tabular}

Some other species targeted on agroforestry for scientific land degradation management are also identified (Kumar, 2005). Australian Wattle (Acacia auriculiformis) is suitable in Agroforestry system. It is conveniently grown along borders of field crops, sometimes laterals removed. It is suitable for checking soil erosion and reducing wastelands. It is suitable to grow on poor soil as it synthesizes atmospheric nitrogen. Not only this, it adds profuse quantity of litter to the soil. 
Khair (Acacia catechu) is suitable to grow for soil conservation. It is useful for afforestation of tropical, dry, arid traits, especially in irrigated and canal plantation. It is useful for social forestry. It is also host for lac insect.

Babul (Acacia nilotica) is best suited in agroforestry system. It has shown excellent performance in soil conservation (sand-dunes stabilization) in dry and arid region of the country. It can be grown along farm boundaries marginal land, tank beds, wasteland like saline and alkaline soil. It is best grown in black cotton soil where other trees hardly survive.

Bael (Aegele marmelos) is a long lived tree; therefore it is suitable to grow on borders of the field that will act a good wind breaker. Time to time lopping will control its canopy 'manageable' that will also reduce shading effects on agricultural crops. This tree is suitable in hortipastoral system. Besides, the bael can be grown in parks, gardens, along road side and canal banks. It produces copious root sucker.

Siris (Albizia lebbeck) is grown as shade tree for plantation crops like tea and cardamom. It is also suitable to grow as wind breaks for the protection of seasonal crops.

Uttish (Alnus nepalensis) is very fast growing trees therefore; it can be selected in Agroforestry system. Its raising is suitably adopted in abandoned tanguay areas where the seed is broad casted during the last year of cultivation. The tree has good capacity for nitrogen fixation therefore avoiding any competition between agricultural crops for nitrogen hunger. It is also good coppicer.

Cashew (Anacardium occidentallis) is planted on poor soils on hill slopes. They help in reducing soil erosion caused by water during rainy season. These species are suitable for hortisilvipastoral system.

Neem (Azadiracta indica) tree is suitable to grow in agroforestry system in which annual crops can easily be grown in the interspaced and even very near to its base. Neem tree does not compete with intercrop because it has deep rooting system. It is suitable to grow in calcareous soil. It is an excellent tree for afforestation of arid region. It is good shade tree grown on farm borders, near buildings and suitable for growing along roadside as an avenue tree and along canal sides. For reclamation of wastelands, growing of Neem, is the best.

Tanki (Bauhinia variegata) is suitable as an attractive ornamental avenue tree. Tree produces good fodder through its leaves therefore planting in field boundaries will benefit growers. It can be tried with other agricultural crop; the tree does not grow large and is readily managed by canopy lopping. Tanki is grown as shelterbelts in coastal areas in mixed planting. The tree has the ability to coppice well and can withstand heavy lopping.

Sissoo (Dalbergia sissoo) is fast growing long lived tree. During early growth up to 4 to 5 years arable crops can easily be grown economically. Thereafter plantation is converted into silvipastoral system. It is suitable to grow as windbreaks and shelterbelts. It acts as good shade tree in tea gardens. Being a leguminous tree it grows well on poor soil as it improves soil fertility. It is also suitable to grow for soil conservation, ravine reclamation etc. It has good coppicing ability and produces root suckers and fixes nitrogen.

Giliricidia (Gliricidia maculate) is very suitable in agroforestry system because it is fast growing species. Unpruned trees act as windbreaks. It is suitably grown along roadsides, on 
the borders of the garden, on wastelands improvement as its roots contain root nodules in which atmospheric nitrogen is fixed.

Ipil-lipil (Leucaena leucocephala) is one of the best trees suitable for agroforestry and social forestry program. It is suitable to grow as windbreaks or shelterbelts. Being a leguminous plant, it improves soil forestry. It is suitable to grow as an effective shade tree for plantation crops like tea, coffee, cocoa, and nursery beds. It has been reported to be most suitable in alley cropping in which it contributes nitrogen and conserves soil moisture. It has strong coppicing and pollarding capacity.

Bakaino (Melia azedarach) is fast growing trees which are very suitable to grow on boundary of the fields. It is also suitable to grow on alkaline soil which is free from water logging conditions. It has beautiful dense foliage, therefore suitable to grow as hedge along roadsides, canal sides and in gardens.

Poplar (Populus spp) is deciduous and has the habit of remaining leafless for 3-4 months and ideal for agrisilviculture and social forestry. Poplar is well suited for growing various vegetables crops, fodder crops, and grasses.

\section{Restoring soil fertility}

Soils in many parts of the mountainous region are already seriously degraded. Restoring fertility levels will be essential if cropping systems are to be intensified. Due to high cost and poor transportation, chemical fertilizer use is limited in the mountainous region, so, in-situ restoration methods for soil fertility must be applied. Relay-cropping of legumes is one of the more promising methods for restoring the soil fertility. Terracing and contour cultivation could minimize soil erosion and help to restore the physical and chemical property of the soil. These restoration methods, however, may only be effective under specific edaphic conditions and have limited applicability on steep slope land (Kerkhoff, 2003).

Maintenance and enhancement of soil fertility is vital for global food security and environmental sustainability. Ecologically sound agroforestry systems such as intercropping and mixed arable-livestock systems can increase the sustainability of agricultural production. Agroforestry is a useful path, complementary to chemical fertilizers, to enhance soil fertility. Alternate land-use systems such as agro-horticultural, agro-pastoral and agro-silvipasture are more effective for soil organic matter restoration. Soil fertility can also be regained in shifting cultivation areas with suitable species. The planting of stem-cuttings and flooding result in greater biological $\mathrm{N}_{2}$ fixation, 307 and $209 \mathrm{~kg} \mathrm{~N}^{-1}$ by Sesbania rostrata and S. cannabina respectively for restoring fertility (Pandey, 2007).

Even when trees are not removed through total harvest, the species combination should be designed for nutrient release that benefits crops. Chemical characteristics and decomposition patterns of six multipurpose tree species, viz. Alnus nepalensis, Albizzia lebbek, Boehmeria rugulosa, Dalbergia sissoo, Ficus glomerata and $F$. roxburghii in a mixed plantation established on an abandoned agricultural land at $1200 \mathrm{~m}$ altitude in Central Himalaya gave the highest rates of $\mathrm{N}$ and $\mathrm{P}$ release during the rainy season. Thus, kharif crops (rainy-season crops) have high nutrients even if leaf litter is the sole source of nutrients to crops in mixed agroforestry. A diverse multipurpose tree community provides diverse products as well as stable nutrient cycling (Kerkhoff, 2003). 
The leaf litters enrich the soil fertility by providing organic matters. Trees leaves control the speed of the raindrops and allow them to go down to the land surface slowly. It helps water to infiltrate into lower part of the soil surface. After the soil is saturated, plants growing on it can utilize the excess water. The excess water is leached to the inner part of soil and supports to originate natural well and streams in the lower areas. It also makes the water table high. Such natural conditions will be favorable for growth of plants and micro-organisms in the soil (Pandey, 2007).

Although trees are expected to improve soil fertility, the extent to which different agroforestry practices depend on tree species, stocking level, growth rate and the input of litter. Achieving synchrony in nutrient release through organic matter turnover is yet another challenging task. This calls for proper selection of tree species, which requires a thorough understanding of the rates and patterns of decomposition and nutrient release (Kafle, 1995).

\section{Reclamation of degraded farmland through agroforestry}

Agroforestry approaches are appropriate to the needs of low resource farmers with physical and socioeconomic constraints. In this regard, Government policies for agricultural, forest land such as per family land holding ceiling, land categorization and taxation based on the land types have to be focused. Stall feeding system will be emphasized. Terrace farming in the hills will be emphasized to reduce the soil loss. Program should be launched with close coordination with farmers or users group in every stage. It should be give attention on balance of land degradation and restoration rates to break further land degradation. Community forestry, private plantation and leasehold forestry concepts are to be implemented effectively in order to reduce human pressure on natural forests. In addition, various alternative methods such as contour farming, strip and alley cropping, and gully improvement activities are to be practiced. More emphasis should be given on formal and non-formal environmental education (Swallow and Ochola, 2006).

\section{CONCLUSION}

The land degradation problem is increasingly becoming a challenge for the economy and natural ecosystems in Nepal. The major causes of land degradation are fragile geological structure, forest fire, avalanches, landslides in the hills, river-damaged areas, deforestation, excessive use of chemical fertilizers, overgrazing and unscientific farming in steep slope, flooding in the plain areas, and shifting cultivation in the mountains. About $45.5 \%, 4 \%$, and $2 \%$ area of the country are affected by water erosion; wind erosion; and chemical and physical processes respectively. It is realized that the balance between the land degradation and restoration rates should be maintained so as not to further degrade the land .Forest and tree cover is declining at alarming rates in Nepal. As a result, essential source of food, fuel, shelter, fodder, medicines, and many other products are disappearing, and the soil and water base for food production is being degraded. Agroforestry, association of trees and shrubs with crops, livestock or other factors of agricultural production, holds great promise for contributing to sustainable land-use systems which can overcome the problem of land degradation and the imminent "food crisis". It provides diversified production and consequently greater food diversity. Agroforestry practices are implicitly assumed to have higher productivity than mono-specific systems, especially on degraded sites. The potential contribution of agroforestry can be effective if farmers and local communities are fully involved in its planning, development and implementation phase. 


\section{REFERENCES}

Brown, L.R., 1981. The global loss of top soil. Soil and water conservation, 36:255-260.

Dent, F.R., 1984. Land degradation: present status, training and education needs in Asia and Pacific. UNEP investigations on environmental education and training in Asia and Pacific: FAO, Regional Office, Bangkok.

Fleming, W.M., 1983. Phewa Tal catchment management program: benefits and costs of forestry and soil conservation in Nepal. In S.H. Lawrence (ed.), Forest watershed development and conservation in Asia and the Pacific, Boulder, Colorado, USA, pp. 217-288.

Gautam M.K., 2000. Social impact assessment of South Asia Poverty Alleviation Programme: Nepal Syanja a pilot study. Impact Assessment Technical Report. SAPAP/UNDP/UNOPS/RAS United Nations Office for Project Services, Kuala Lumpur, Malaysia.

Gautam, M.K., E.H. Robert and B.K. Singh, 2003. Report on community based leasehold approach and agroforestry technology for restoring degraded Hill Forests and proving rural livelihoods in Nepal, Forest and Biodiversity Conference, Kathmandu, Nepal.

Kafle, S.K., 1995. Reclamation of river-damaged areas through agroforestry in Nepal: A case study of Midhills Region Nepal, Unpublished MPA thesis submitted to Tribhuvan University, Kirtipur.

Karkee, K., 2004. Land degradation in Nepal: A menace to economy and ecosystems international Master's Programme in environmental science, University of Lund, Sweden.

Kerkhoff, E.E., 2003. Sustainable sloping lands and watershed management conference (ICIMOD), Kathamndu.

Kumar, B.M., 2005. Carbon sequestration potential of tropical homegardens. In: Tropical Homegardens: A time-tested example of sustainable agroforestry, Kumar, B.M. and Nair, P.K.R. (eds). Springer Science, Dordrecht, The Netherlands, pp. 185-204.

LRMP, 1986. Forestry land use report Mimeograph, Topographical Survey Branch, Kathmandu.

MoEST, 2006. Rural Energy Policy. Ministry of Environment Science and Technology, Kathmandu.

MoEST, 2008. Thematic assessment report on land degradation. Ministry of Environment, Science and Technology; Government of Nepal, Kathmandu ,Nepal

Neupane, R.P. and G.B. Thapa, 2001. Impact of agroforestry intervention on farm income under the subsistence farming system of the middle hills, Nepal. Agroforest. Syst., 53: 31-37.

Pandey, D.N., 2007. Multifunctional agroforestry systems in India .Current Science, vol. 92, no. 4, 25 February 2007

Regmi, B.N., 1998. Program dynamics of the Nepal Agroforestry Foundation in Majhitar of Dhading District, Nepal. Unpublished MS Thesis, University of the Philippines, Los Baños, College, Laguna.

Swallow, B and S. Ochola, 2006. Understanding the Links between Agriculture and Health, International Food Policy Research Institute ; Washington, U.S.A.

Uhl, C., 1987. Factors controlling succession following slash and burn agriculture in Amazonia. Journal of Ecology, 75: 377-407.

Uhl, C. and R. Buschbacher, 1985. A disturbing synergism between cattle ranch burning practices and selective tree harvesting in the eastern Amazon. Biotropica, 17: 265-268. 